The entomological course given at the Griduate School of Agriculture, held last month at Cornell Cuiversity. has been well attended, and the entire session has been considered most successful by those responsible fir the venture.

The Quebec Society for the Protection of Plants (from inserts and fungus pests), was organized at a meeting held June 24 at Mracdonald College. This society, as its name indicates, will be strongly of an economic nature. The hemlquarters for the soriety will be, for the present, aradonald College. The following officers were elected for the ensuing year:

President, Prof. W. Tockheat, Machonald College: Vica-l'resident. Frère Lignori. La Trappe, Ola, P. Q.; Secretary-Treasurer, Douglas Weir. Manedonald College; Curator and Libmrian, J. M. Swaine, Macdonald collese; Directors, Rev. Dr. Fyles, Levis, I'. Q., Rev. G. Incharme, Rigaud. I'. Q., A. F. Winn, Montreal, Auguste Dupuis, Village des Aulnaies, Dr. W. Grignon, Ste Adèle.

A substantial grant has been giren the Society by the Quebec Department of Agriculture. As a large number of persons in the I'rovince of Qneber are interested in the study of inserts and fungi, it is believerl that the new society will have il large membership, and will be able to do at great deal of work in the interests of agriculture.

Economic Entomology at Harvard Cuiversity-Replying to an incuiry. Prof. W. M. Wheeler states that during the coming year only two courses will be given; one by Limself on the "Structure, Development amd IIabits of Insects," and one by Mr. Paul Hayhurst, recently appointed instructor. on "Common Economic Insects," both being intended primarily for srialuate students. These courses begin February 1, 1909, the first semester being reserved for research work. Provision for the latter, commencing October 1 of the present year, has been macte at the Bussey Institution, Forest HIlls, Mass., where the entomological laboratories are situnted.

\title{
Elm Leaf Beetle
}

Galerucella luteola Mull. The ritvages of this pest continue in New York state, the elms of Albany, Troy, Schenectady, Schuylerville, Ithaca and those of some other locnlities in the Hudson Valley at least, being very hally injured, despite more or less sporadic efforts to control the insect. This species, under favorable conditions, produces two generations annually in the lititule of Albany. The experience of the past ten years has shown that the area of grentest injury in Albany is restricted to the older and more thickly settleyl fourth of the city. 'The comparatire immunity of other parts of the mumicipality is probably due to the greater abundance of native birds, and presmuably in part to fewer shelters where the beetles can hibernate successfully. This marked restriction was likewise very evident in schenectady, the rmyages of the beetle being particularly marked in the vicinity of an open belfry where the insects undoubtedly hibermated in large numbers.

E. P. Fret, Albany, N. Y.

Mailed August 15, 1908. 